\title{
REVIEW \\ Introduction of Non-native Predatory Mites for Pest Control and its Risk Assessment in Japan
}

\author{
Yukie SATO ${ }^{1}$, Masatoshi MOCHIZUKI ${ }^{2 *}$ and Atsushi MOCHIZUKI ${ }^{1}$ \\ ${ }^{1}$ National Institute for Agro-Environmental Sciences (Tsukuba, Ibaraki 305-8604, Japan) \\ ${ }^{2}$ NARO Institute of Fruit Tree Science, National Agriculture and Food Research Organization \\ (Okitsu, Shimizu, Shizuoka 424-0292, Japan)
}

\begin{abstract}
The use of natural enemies instead of chemical pesticides has been increasing worldwide. Although non-native natural enemies are beneficial and commonly used as biological control agents, the risks of non-target effects caused by their release are of growing concern. Phytoseiid mites are a very common choice as introduced biological control agents. In Japan, 8 species of non-native phytoseiid mites, one of which is the same as the native type but originates from a non-native population, have been introduced for crop pest control. There is concern about the influence of the introduced phytoseiid mites on native phytoseiid mites that occupy a similar habitat, but very few risk assessments of these phytoseiid mites have been carried out in Japan. In this paper, we estimate the risks of the nontarget effect caused by the release of these introduced non-native phytoseiid mites by using the risk indexes proposed by Mochizuki (2010), and briefly present the results of monitoring the species considered at risk from the release of non-natives.
\end{abstract}

Discipline: Insect pest

Additional key words: Acari, biological control, exotic natural enemy, non-target effect, phytoseiid mite

\section{Introduction}

Pest control is one of the key problems in agriculture. Although many natural and synthetic chemicals such as nicotine and DDT have been used to control crop pests, chemical pesticides have been shown to harm the health of living creatures, both animals and humans, while their repeated use results in pests becoming resistant. In 1889, the vedalia beetle, Rodolia cardinalis (Mulsant), was imported into California from Australia to control an invasive alien pest insect, the cottony cushion scale, Icerya purchasi Maskell, and successfully controlled the pest insects ${ }^{3}$. Since this success, using natural enemies as a form of biological control has gained global attention as a less harmful method than the application of chemical pesticides ${ }^{36}$. To control invasive alien pests, many natural enemies have been imported from the original country of the pests ${ }^{36}$. Releasing (augmenting) these natural enemies has also been performed to supplement any lack of natural enemies and to control pests inside greenhouses in their absence ${ }^{36}$.

Recently, concerns have been raised that the import and release of non-native natural enemies may have nontarget effects on native ecosystems ${ }^{2,32,33,36}$. For example, a non-native lady beetle, Coccinella septempunctata L., was introduced into North America and released to control pest aphids on several crops, but after release, the native lady beetles, especially C. transversoguttata richardsoni Brown and Adalia bipunctata (L.), sharply declined and were partly displaced by the non-native lady beetle?. In 1996, the Food and Agriculture Organization (FAO) published a "Code of conduct for the import and release of exotic biological control agents," sparking a global trend for the risk assessment of natural enemies prior to their import overseas ${ }^{2}, 32,33$.

Phytoseiid mites (Acari: Phytoseiidae) are a very common choice as biological control agents worldwide for controlling pest mites, thrips and whiteflies. As of 2003, more than 2000 species of phytoseiid mites had been reported globally, 85 of which were reported in Japan $^{8}$. Phytoseiid mites are tiny: females are 0.3 to 0.6

*Corresponding author: e-mail mmochizu@affrc.go.jp

Received 28 December 2010; accepted 11 July 2011. 
$\mathrm{mm}$ in length, but their predation activity is considerable $^{28}$. Their reproductive rate is also high and comparable to that of prey species ${ }^{27}$. Therefore, they were examined as a biological control agent at an early stage, and promising species were exported and imported ${ }^{36}$. Phytoseiulus persimilis Athias-Henriot was introduced into Japan in 1966, for basic and applied research as a biological control agent for greenhouse horticultural pest insects, and was the first species to be registered as a biological pesticide ${ }^{36}$. Since the introduction of $P$. persimilis, several non-native phytoseiid mite species have been introduced and released in Japan (Table 1). New non-native phytoseiid mites are awaiting introduction and release into Japan, and the effective use of these new species, as well as those already imported, is being investigated. However, there has still been little investigation into the purpose of risk assessment of the non-target effect in Japan. In this paper, we estimate the risks of the non-target effect caused by the release of these introduced non-native phytoseiid mites by calculating their risk indexes as proposed by Mochizuki (2010) $)^{21}$, and briefly present the results of monitoring the species considered at risk from the release of non-natives. We discuss the risks of releasing these introduced non-native phytoseiid mites and the role of risk assessment on these mites in terms of improving the risk assessment method.

\section{Estimated risk of the non-target effect caused by the release of non-native phytoseiid mites}

In Japan, the Ministry of the Environment announced its "Guidelines on Introduction of Environmental Impact Assessment of Biological Control Agents" in 199920,36. The Agricultural Chemicals Inspection Station performs an ecological risk assessment of non-native biological control agents following the guideline and makes decisions about their import and use ${ }^{20,36}$. This guideline presents a stepwise procedure, and covers the important information needed for the risk assessment of non-native natural enemies ${ }^{20,36}$. Mochizuki $(2010)^{21}$ pointed out, however, that this guideline is qualitative, and that a quantitative method such as that proposed in Europe by the EU-funded research project ERBIC (Evaluating Environmental Risks of Biological Control Introductions into Europe $)^{32}$ is needed. In the ERBIC method, the risk is evaluated by calculating the risk index, in which the scores of likelihood (probability) and magnitude (consequence) are multiplied in each assessment element, and the assessment element scores collectively totaled up. Mochizuki (2010) $)^{21}$ arranged this method to be practical in Japan, where it was proposed as a new form of objective risk assessment. We summarize the method briefly, and estimate the risk index of already introduced non-native phytoseiid mites.

\section{Risk assessment method proposed by Mochizuki $(2010)^{21}$}

First, risk index-1 is calculated by adding the scores of the three elements "establishment", "dispersal" and "host range." Each element score is calculated by multiplying the score of likelihood (L) and magnitude (M) (Table 2). Provided the risk index-1 doesn't exceed 40, it's decided that the risk is low, and the introduction of the species is permitted without further research. This cutoff line of a risk index- 1 of 40 is based on the score of the vedalia beetle, which was introduced in 1911 to control the cottony cushion scale and has been established without unwelcome non-target effects in Japan. When the risk index-1 exceeds 40 , it is decided that information on the risk is insufficient to grant permission for the introduction pending further research, and the total risk index must be calculated, whereby the scores of three additional elements, "direct effect on rare or endemic species," "competition with native species" and "hybridization

Table 1. Phytoseiid mites introduced for biological control in Japan

\begin{tabular}{|c|c|c|c|c|}
\hline & Phytoseiid mite & Target pests & Use in & $\begin{array}{l}\text { [Introduction or } \\
\text { registration] year }\end{array}$ \\
\hline \multirow{5}{*}{$\begin{array}{l}\text { Commercially supplied } \\
\text { (Augmentation) }\end{array}$} & Phytoseiulus persimilis & Spider mites & Greenhouse & 1995 \\
\hline & Neoseiulus californicus & Spider mites & Greenhouse \& Open field & 2003 \\
\hline & Neoseiulus cucumeris & Thrips & Greenhouse & 1998 \\
\hline & Iphiseius degenerans & Thrips & Greenhouse & 2003 \\
\hline & Amblyseius swirskii & Thrips, [whiteflies] & Greenhouse & 2008 \\
\hline \multirow{3}{*}{$\begin{array}{l}\text { Experimentally released } \\
\text { (Classical biological control) }\end{array}$} & Galendromus occidentalis & Spider mites & Open field & 1986 \\
\hline & Neoseiulus fallacis & Spider mites & Open field & 1986 \\
\hline & Typhlodromus pyri & Spider mites & Open field & 1986 \\
\hline
\end{tabular}


with native species," are added to risk index-1. Provided the total risk index does not exceed 80, the introduction of the species is permitted but carefully, for example, accompanied with monitoring of the species. When the index exceeds 80 , the introduction of the species should not be permitted without restriction, for example, the species may only be used in completely sealed greenhouses.

\section{Risk index-1 of introduced non-native phytoseiid mites}

The score of each element required in the risk index-1 calculation of introduced non-native phytoseiid

Table 2. Scores of likelihood $(\mathrm{L})$ and magnitude $(M)$ in six elements used to calculate risk index-1 and total risk index in Mochizuki (2010) $)^{21}$

\begin{tabular}{|c|c|c|c|c|c|c|}
\hline \multirow[b]{3}{*}{ Score } & \multicolumn{6}{|c|}{ Element } \\
\hline & \multicolumn{3}{|c|}{ For the risk index-1 } & \multicolumn{3}{|c|}{ For the total risk index } \\
\hline & Establishment & Dispersal $^{1}$ & Host range $^{2}$ & $\begin{array}{l}\text { Direct effect on rare } \\
\text { or endemic species }\end{array}$ & $\begin{array}{l}\text { Competition with } \\
\text { native species }\end{array}$ & $\begin{array}{l}\text { Hybridization with } \\
\text { native species }\end{array}$ \\
\hline 1 & $\begin{array}{l}\text { Cannot pass winter or } \\
\text { summer }\end{array}$ & $<1$ week & $<1 \mathrm{~mm}$ & $\begin{array}{l}\text { Habitat and time; } \\
\text { different from them }\end{array}$ & $\begin{array}{l}\text { Not the same host } \\
\text { range }\end{array}$ & No \\
\hline 2 & $\begin{array}{l}\text { One brood/year, } \\
\text { non-diapause }\end{array}$ & 1 - 2 weeks & $1 \mathrm{~mm}-3 \mathrm{~mm}$ & $\begin{array}{l}\text { Very often the same } \\
\text { habitat and time }\end{array}$ & $\begin{array}{l}\text { Host range } 10-30 \% \\
\text { overlap }\end{array}$ & $\begin{array}{l}\text { Low interspecific } \\
\text { hybridization }\end{array}$ \\
\hline 3 & $\begin{array}{l}\text { Over two broods /year, } \\
\text { non-diapause }\end{array}$ & $2-3$ weeks & $3 \mathrm{~mm}-5 \mathrm{~mm}$ & $\begin{array}{l}\text { Partially overlapping } \\
\text { habitat }\end{array}$ & $50 \%$ overlap & $\begin{array}{l}\text { High, sex ratio: not } \\
50 \%\end{array}$ \\
\hline 4 & $\begin{array}{l}\text { One brood/year, can } \\
\text { diapause }\end{array}$ & 3 - 4 weeks & $5 \mathrm{~mm}-10 \mathrm{~mm}$ & $50 \%$ overlap & $60-80 \%$ overlap & High, sex ratio: $50 \%$ \\
\hline 5 & $\begin{array}{l}\text { Over two broods /year, } \\
\text { can diapause }\end{array}$ & $>1$ month & $>10 \mathrm{~mm}$ & Always overlap & The same host range & Hybrid vigor \\
\hline \multicolumn{7}{|c|}{$\begin{array}{l}\text { 1: Longevity } \\
\text { 2: Feeding amounts approximated by body length when introduced }\end{array}$} \\
\hline \multicolumn{7}{|c|}{ M: magnitude } \\
\hline & \multicolumn{6}{|c|}{ Element } \\
\hline & \multicolumn{3}{|c|}{ For the risk index-1 } & \multicolumn{3}{|c|}{ For the total risk index } \\
\hline Score & Establishment & Dispersal $^{3}$ & Host range $^{4}$ & $\begin{array}{l}\text { Direct effect on rare } \\
\text { or endemic species }\end{array}$ & $\begin{array}{l}\text { Competition with } \\
\text { native species }\end{array}$ & $\begin{array}{l}\text { Hybridization with } \\
\text { native species }\end{array}$ \\
\hline 1 & Local in Japan & $<10 \mathrm{~cm} / \mathrm{s}$ & Genus & $\begin{array}{l}\text { Does not eat rare/ } \\
\text { endangered species }\end{array}$ & Even or inferior & $\begin{array}{l}\text { Morphologically } \\
\text { different }\end{array}$ \\
\hline 2 & $<10 \%$ of Japan & $10-50 \mathrm{~cm} / \mathrm{s}$ & Family & $\begin{array}{l}\text { Can eat species } \\
\text { related to the rare } \\
\text { one but cannot grow } \\
\text { only with them }\end{array}$ & $\begin{array}{l}\text { Coexistence with } \\
\text { host }\end{array}$ & $\begin{array}{l}\text { Uses different } \\
\text { courtship signal }\end{array}$ \\
\hline 3 & $10-25 \%$ & $50 \mathrm{~cm} / \mathrm{s}-1 \mathrm{~m} / \mathrm{s}$ & Order & $\begin{array}{l}\text { Does not prefer them } \\
\text { in a choice test }\end{array}$ & $\begin{array}{l}\text { Wins against } 1-2 \\
\text { species }\end{array}$ & $\begin{array}{l}\text { Females can mate } \\
\text { many times }\end{array}$ \\
\hline 4 & $25-50 \%$ & $1 \mathrm{~m} / \mathrm{s}-2 \mathrm{~m} / \mathrm{s}$ & Class & $\begin{array}{l}\text { Eats them and pest } \\
\text { species equally }\end{array}$ & $\begin{array}{l}\text { Wins against several } \\
\text { species }\end{array}$ & $\begin{array}{l}\text { Females mate only } \\
\text { twice or three times }\end{array}$ \\
\hline 5 & $>50 \%$ & $>2 \mathrm{~m} / \mathrm{s}$ & Phylum or so & $\begin{array}{c}\text { Prefers rare/ } \\
\text { endangered species }\end{array}$ & Always wins & $\begin{array}{l}\text { Females mate only } \\
\text { once }\end{array}$ \\
\hline
\end{tabular}

3: Flight or walking speed of the introduced stage

4: Relationship with target species 
mites was estimated as described below.

(1) Establishment

Likelihood. The phytoseiid mite is multivoltine. Experimentally introduced phytoseiid mites naturally enter a reproductive diapause in winter ${ }^{26}$, but those commercially introduced are non-diapause species or strains ${ }^{10,26,31,35}$. This is because these commercially introduced mites are often used for pest control in greenhouses, where nondiapause alien pest arthropods thrive, even in winter.

Magnitude. It is expected that experimentally introduced phytoseiid mites will be able to establish themselves all over Japan, due to their overwintering ability. Conversely, it is expected that commercially introduced phytoseiid mites will be able to establish themselves in southwestern Japan, since non-diapause Neoseiulus californicus (McGregor) has increased in orchards in central and southwestern Japan recently, replacing diapause Neoseiulus womersleyi (Schicha) $)^{1,10}$. However, the recent increase of $N$. californicus has been dramatic (a phenomenon of the past 20-30 years ${ }^{1}$ ), and an artificial effect on the increase and range expansion is suspected ${ }^{1,10,11}$. Accordingly, further study would be necessary for attentive risk assessment.

(2) Dispersal

Likelihood. The longevity of the phytoseiid mite adult depends on temperature and food availability, but with their life history data in mind, phytoseiid mite adults of all species are expected to survive for at least three to four weeks ${ }^{29}$.

Magnitude. Phytoseiid mites are small wingless arthropods with a walking speed of less than $10 \mathrm{~cm} / \mathrm{s}^{17}$. However, aerial dispersal behavior after being drawn actively into the airstream was observed in several species of phytoseiid mites, including three that were experimentally introduced ${ }^{4,6,12,14}$. While in flight, the mites can be dispersed over more than $100 \mathrm{~m}^{16}$. Although the mites cannot control their landing ${ }^{15}$, this aerial dispersal might allow them to be dispersed at speeds greater than $2 \mathrm{~m} / \mathrm{s}$.

(3) Host range

Likelihood. The body of the phytoseiid mite is less than $1 \mathrm{~mm}$, so its feeding amount is expected to be negligible in all species ${ }^{8}$.

Magnitude. The commercially introduced species $P$. persimilis is a specialized predator of the Tetranychus species having a web structure ${ }^{19}$. The commercially introduced species $N$. californicus and two experimentally introduced species, Galendromus occidentalis (Nesbitt) and Neoseiulus fallacis (Garman), are selective predators of the tetranychid mites having a web structure, including Tetranychus species, hence the selective predators show a broader range for preying compared to the specialized predators $^{19}$. Conversely, three commercially introduced species, Neoseiulus cucumeris (Oudemans), Iphiseius degenerans (Berlese) and Amblyseius swirskii Athias-Henriot, and an experimentally introduced species, Typhlodromus pyri Scheuten, are generalist predators that feed not only on target pests such as mites, thrips and whiteflies but also on coccids, honeydew and pollen ${ }^{18,19,25,34}$.

Table 3 shows the results of risk index-1 calculation in the introduced non-native phytoseiid mites. The risk indexes-1 of commercially introduced mites were under 40, and this result would support the appropriateness for permission for the introduction and release of commercially introduced mites. Conversely, the risk indexes- 1 of experimentally introduced mites exceeded the cutoff point of 40, which indicates that their introduction should not have been permitted without caution or restrictions.

\section{Monitoring of experimentally introduced non-native phytoseiid mites}

Three non-native phytoseiid mites, G. occidentalis, $N$. fallacis and T. pyri, with resistance against pesticides, were introduced as agents to control pest mites in apple orchards from New Zealand to Aomori Prefecture, Japan, in $1986^{24}$. In several countries (e.g. New Zealand, Australia and North America), pesticide-resistant strains of these mites are effectively used as biological control agents in orchards combined with chemical control as Integrated Pest Management ${ }^{13}$. Part of the mite culture in Aomori Prefecture was transferred to Akita and Nagano prefectures, and the mites were experimentally released to control pest mites in apple orchards (Table 4) 22, 23, 24 . Increased numbers after release and the overwintering of G. occidentalis and N. fallacis were confirmed from 1987 to 1988 in Aomori Prefecture ${ }^{24,30}$, while those of G. occidentalis were confirmed from 1988 to 1989 in Akita Prefecture $^{22}$. Their increases and overwintering in the orchards were regarded as positive, because the release of these introduced mites was conducted as an instance of classical biological control. Conversely, these mites are not currently used as biological control agents, and concern has arisen over the non-target effects on native phytoseiid mites caused by this release of non-native phytoseiid mites. To monitor the establishment of these mites and their effects on the native phytoseiid mites, Mochizuki et al. (2003, 2004, 2005) conducted a species composition survey of phytoseiid mites in these areas ${ }^{22,23,24}$.

The surveys of $G$. occidentalis, $N$. fallacis and $T$. pyri were conducted in the season when pest spider mites and phytoseiid mites proliferated: August 2003 in Aomori Prefecture (11 years after the last release), August 2002 in Akita Prefecture (3 years after the last release) and 
July 2004 in Nagano Prefecture (13 years after the last release). In Akita Prefecture, a supplemental survey was conducted in August 2007 (8 years after the last release), since a non-native mite, G. occidentalis, was found in the undergrowth of cherry and apple trees in Aomori Prefecture at least 8 years after the last release ${ }^{24}$. Leaves from apple, cherry, peach and willow trees were collected from the apple orchards where the non-native mites had been released and the surrounding areas. The existence of phytoseiid mites on these leaves was checked, and those found were prepared as slide specimens. The species were subsequently checked using phase microscopes and an identification table.

Figure 1 shows the results of the surveys. Non-native phytoseiid mites were not found in any of these three prefectures. The identified phytoseiid mites were $N$. womersleyi, Typhlodromus vulgaris Ehara, N. calforni- cus and Euseius finlandicus (Oudemans). Unfortunately, it is not possible to compare the species composition before and after the non-native mite release, since no prerelease species composition surveys were conducted. However, all the mites identified were phytoseiid mite species commonly found in each area. Therefore, it appears that the non-native mites failed to establish themselves in these areas, or the effect on the native mites was negligible, even if they had established themselves there.

Many non-native mites were released in Aomori and Akita prefectures (Table 4), and their proliferation after release and overwintering were confirmed in both prefectures. Why did these non-native mites (resistant to pesticides) fail to establish themselves in these areas? One possible explanation is exclusion by the native phytoseiid mites ${ }^{24}$. There are reports that G. occidentalis is often displaced by other phytoseiid mites because of its

Table 3. The risk index-1 of the introduced non-native phytoseiid mites as calculated by the risk assessment method proposed by Mochizuki (2010) ${ }^{21}$

\begin{tabular}{|c|c|c|c|c|c|c|}
\hline & Species & & Establishment & Dispersal & Host range & Risk index-1 (Total) \\
\hline \multirow{15}{*}{$\begin{array}{l}\text { Commercially introduced } \\
\text { (Augmentation) }\end{array}$} & \multirow{3}{*}{ P. persimilis } & $\mathrm{L}$ & 3 & 4 & 1 & \\
\hline & & M & 4 & 5 & 1 & \\
\hline & & $\mathrm{L} \times \mathrm{M}$ & 12 & 20 & 1 & 33 \\
\hline & \multirow{3}{*}{ N. californicus } & $\mathrm{L}$ & 3 & 4 & 1 & \\
\hline & & M & 4 & 5 & 2 & \\
\hline & & $\mathrm{L} \times \mathrm{M}$ & 12 & 20 & 2 & 34 \\
\hline & \multirow{3}{*}{ N. cucumeris } & $\mathrm{L}$ & 3 & 4 & 1 & \\
\hline & & M & 4 & 5 & 5 & \\
\hline & & $\mathrm{L} \times \mathrm{M}$ & 12 & 20 & 5 & 37 \\
\hline & \multirow{3}{*}{ I. degenerans } & $\mathrm{L}$ & 3 & 4 & 1 & \\
\hline & & M & 4 & 5 & 5 & \\
\hline & & $\mathrm{L} \times \mathrm{M}$ & 12 & 20 & 5 & 37 \\
\hline & \multirow{3}{*}{ A. swirskii } & $\mathrm{L}$ & 3 & 4 & 1 & \\
\hline & & M & 4 & 5 & 5 & \\
\hline & & $\mathrm{L} \times \mathrm{M}$ & 12 & 20 & 5 & 37 \\
\hline \multirow{9}{*}{$\begin{array}{l}\text { Experimentally introduced } \\
\text { (Classical biological control) }\end{array}$} & \multirow{3}{*}{ G. occidentalis } & $\mathrm{L}$ & 5 & 4 & 1 & \\
\hline & & M & 5 & 5 & 2 & \\
\hline & & $\mathrm{L} \times \mathrm{M}$ & 25 & 20 & 2 & 47 \\
\hline & \multirow{3}{*}{ N. fallacis } & $\mathrm{L}$ & 5 & 4 & 1 & \\
\hline & & M & 5 & 5 & 2 & \\
\hline & & $\mathrm{L} \times \mathrm{M}$ & 25 & 20 & 2 & 47 \\
\hline & \multirow{3}{*}{ T. pyri } & $\mathrm{L}$ & 5 & 4 & 1 & \\
\hline & & M & 5 & 5 & 5 & \\
\hline & & $\mathrm{L} \times \mathrm{M}$ & 25 & 20 & 5 & 50 \\
\hline
\end{tabular}


less competitive ability, but it is often dominant in intensively sprayed sites ${ }^{5}$. In Aomori Prefecture, spraying of pesticides was reduced after the release of these introduced mites ${ }^{24}$. If native phytoseiid mites were excluded by pesticide spray, these introduced mites might have had the opportunity to occupy these orchards.

\section{Conclusion}

The estimated risk indexes-1 suggest the need for further assessment in experimentally introduced phytoseiid mites and that they should not have been released without caution or restriction (Table 3). However, in the species composition surveys performed to monitor these

Table 4. Release records of the non-native phytoseiid mites into apple orchards $\mathrm{s}^{22,23,24}$

(a) Aomori Prefecture

\begin{tabular}{rcccr}
\hline \hline Year & Month & Site & Mite Species & \multicolumn{1}{c}{ Number } \\
\hline 1986 & Aug.-Sep. & Field 1 & G. occidentalis & 1,100 \\
& & & N. fallacis & 1,000 \\
1987 & July & Field 1 & G. occidentalis & 420 \\
1988 & May & Field 2 & N. fallacis & No description \\
1989 & June-July & Field 1 & G. occidentalis & No description \\
& & & N. fallacis & No description \\
& & & T. pyri & No description \\
1990 & May, Aug. & Field 1 & T. pyri & 400 \\
1991 & June-July & Field 1 & G. occidentalis & 140 \\
& & & N. fallacis & 140 \\
1992 & July & Field 1 & T. pyri & No description \\
& & & N. fallacis & 1,500 \\
& & & & 176,000
\end{tabular}

(b) Akita Prefecture

\begin{tabular}{rcccr}
\hline \hline Year & Month & Release site & Mite Species & \multicolumn{1}{c}{ Number } \\
\hline 1988 & June-Aug. & Field 3 & G. occidentalis & 5,000 \\
1989 & June-Aug. & Field 3 & G. occidentalis & 4,000 \\
1990 & July & Field 4 & G. occidentalis & 1,000 \\
1990 & Aug. & Field 5 & G. occidentalis & 1,200 \\
1992 & July-Aug. & Field 6 & G. occidentalis & 2,600 \\
1996 & July-Aug. & Field 7 & G. occidentalis & No description \\
1997 & July & Field 7 & G. occidentalis & No description \\
1999 & July & Field 7 & G. occidentalis & No description \\
\hline
\end{tabular}

(c) Nagano Prefecture

\begin{tabular}{ccccr}
\hline \hline Year & Month & Release site & Mite Species & \multicolumn{1}{c}{ Number } \\
\hline 1990 & July & Field 8 & G. occidentalis & 3,150 \\
1991 & July & Field 8 & G. occidentalis & 2,150 \\
\hline
\end{tabular}

Field 1 \& 2: Apple orchards in Aomori Apple Experiment Station (Kuroishi)

Field 3: Apple orchard in Akita Fruit-Tree Experiment Station (Kaidoshita, Hiraka)

Field 4: Apple orchard in Sawaguchi, Masuda

Field 5: Apple orchard in Akesawa, Masuda

Field 6: Apple orchard in Hansuke, Masuda

Field 7: Apple orchard in Tokufuji, Inagawa

Field 8: Apple orchard in Nagano Fruit Tree Experiment Station (Suzaka) 
experimentally introduced phytoseiid mites several years after their release, these mites were not found, and there were no causes for alarm in terms of the species composition (Fig. 1) 22, 23, 24. Therefore, Mochizuki et al. (2003, 2004, 2005) concluded that no serious non-target effects on native phytoseiid mites would be caused by the release of these experimentally introduced mites ${ }^{22,23,24}$.

Conversely, the risk index-1 of commercially introduced mites was under the cutoff of 40 (Table 3), which indicates no need for further assessment regarding permission for their introduction. However, there are recent suspicions that these commercially introduced phytoseiid mites might have established themselves in Japan and affected the native phytoseiid mites. For example, when estimating the score of these species for the "establishment" element, we referred to the recent dramatic increase of $N$. californicus in central and southwestern Japan, replacing $N$. womersleyi ${ }^{1}$. N. californicus has been in Japan since before the introduction of its non-native strain 7 , but it was naturally suspected that the dramatic increase of $N$. californicus replacing $N$. womersleyi was caused by the widespread use of commercially introduced $N$. californicus. The factors behind the dramatic increase of $N$. californicus replacing $N$. womersleyi were investigated from the perspectives of pesticide susceptibility, cold hardiness and genetic diversity in native and commercially introduced strains of $N$. californicus and the native $N$. womersleyi ${ }^{1,10,11}$. The results of these studies suggest it is unlikely that the widespread use of the introduced strain of $N$. californicus was the main factor in the disappearance of $N$. womersleyi. However, the reason for the disappearance remains unclear, and the involvement of commercially introduced $N$. californicus has not been completely ruled out.

We consider it wise to perform further assessment of commercially introduced non-native phytoseiid mites, which would help clarify their risks and reduce unnecessary suspicions. In addition, the further assessment would be useful for improving the risk assessment method. The history of natural enemy introduction, especially commercially, is still short in Japan, hence the lack of data concerning the influence of repeated releases over

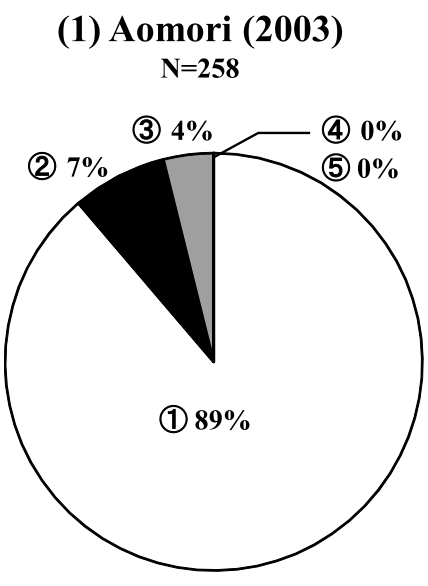

(3) Akita (2007)

$\mathrm{N}=126$

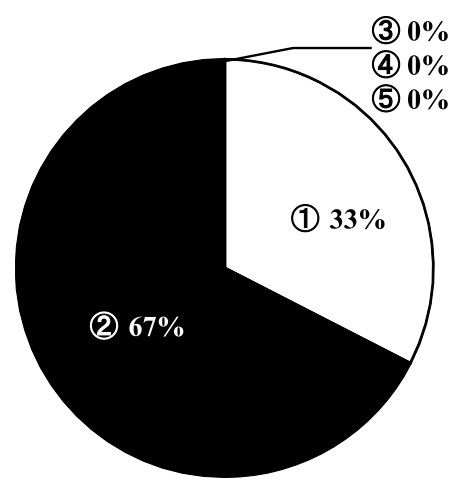

(2) Akita (2002) $\mathbf{N}=\mathbf{2 2 2}$

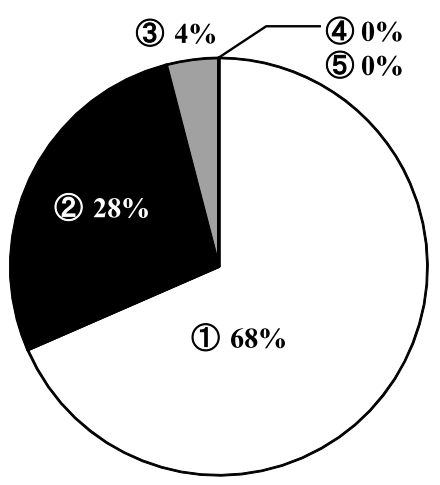

(4) Nagano (2004) $\mathrm{N}=378$

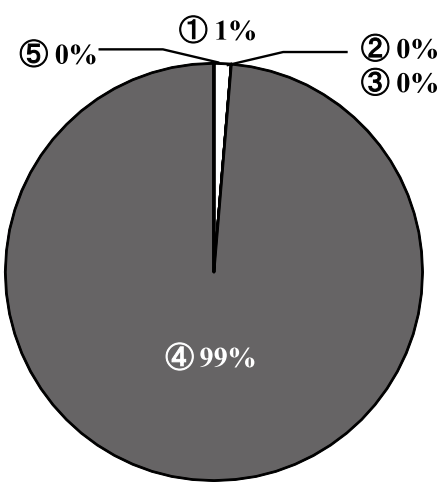

Fig. 1. Species composition of female phytoseiid mites in surveys conducted in (1) Aomori, 2003 ${ }^{24}$, (2) Akita, 2002 ${ }^{22}$, (3) Akita, 2007 (Sato et al. unpublished data) and (4) Nagano, 2004 23

$\square$ : (1)T. vulgaris, $\square$ : (2) N. womersleyi, $\square$ : (3) E. finlandicus, $\square$ : (4) N. californicus, $\square$ : (5)Non-native mite. 
an extended period. We have to continue improving the risk assessment method using newly gathered data. These phytoseiid mites are good for this activity, since they were commercially introduced into Japan early, and their amount and the number of species involved has been increasing year by year. Introduced non-native natural enemies are mainly used to control invasive alien pest arthropods, which carry much greater risks than non-native natural enemies. Therefore, we must be prudent, not only in permitting but also rejecting the introduction of nonnative natural enemies. To avoid granting permission without due consideration as well as excessive rejection, study including perspectives of the effective use as biological control agents and the risk assessment of non-target effects in non-native phytoseiid mites would be important.

\section{Acknowledgments}

We thank Drs. Ken Funayama at the Akita FruitTree Experiment Station, Yoshiko Kimura at the Institute of Apple Research, Aomori Prefectural Industrial Technology Research Center and Terunori Sasawaki at the Nagano Fruit Tree Experiment Station for their cooperation in the data collection concerned with experimentally released phytoseiid mites. We also thank Dr. Hiroshi Amano at Kyoto University for his advice regarding the identification of phytoseiid mite species. This research was partly supported by the fund from the Japan Society for the Promotion of Science for Young Scientists (no. 1045).

\section{References}

1. Amano, H., Ishii, Y. \& Kobori, Y. (2004) Pesticide susceptibility of two dominant phytoseiid mites, Neoseiulus californicus and $N$. womersleyi, in conventional Japanese fruit orchards (Gamasina: Phytoseiidae). J. Acarol. Soc. Jpn., 13, 65-70.

2. Bigler, F., Babendreier, D. \& Kuhlmann, U. (2006) Environmental impact of invertebrates for biological control of arthropods. CABI Publishing, Wallingford, UK, pp.299.

3. Caltagirone, L. E. \& Doutt, R. L. (1989) The history of the vedalia beetle importation to California and its impact on the development of biological control. Annu. Rev. Entomol., 34, 1-16.

4. Croft, B. A. \& Jung, C. (2001) Phytoseiid dispersal at plant to regional levels: a review with emphasis on management of Neoseiulus fallacis in diverse agroecosystems. Exp. Appl. Acarol., 25, 763-784.

5. Croft, B. A. \& Luh, H.-K. (2004) Phytoseiid mites on unsprayed apple trees in Oregon, and other western states (USA): distributions, life-style types and relevance to commercial orchards. Exp. Appl. Acarol., 33, 281-326.

6. Dunley, J. E. \& Croft, B. A. (1990) Dispersal between and colonization of apple by Metaseiulus occidentalis and Typhlodromus pyri (Acarina: Phytoseiidae). Exp. Appl. Acarol., 10, 137-149.

7. Ehara, S. (1964) Some mites of the families Phytoseiidae and Blattisocidae from Japan (Acarina: Mesostigmata). Jour. Fac. Sci. Hokkaido Univ. Ser. VI, Zool., 15, 378-394.

8. Ehara, S. (2005) A guide to the phytoseiid mites of Japan (Acari: Phytoaseiidae). Shokubutsu boeki (Plant Prot.), 59, 177-182 [In Japanese].

9. Elliott, N., Kieckhefer, R. \& Kauffman, W. (1996) Effects of an invading coccinellid on native coccinellids in an agricultural landscape. Oecologia, 105, 537-544.

10. Gotoh, T. et al. (2005) Cold hardiness of Neoseiulus californicus and N. womersleyi (Acari: Phytoseiidae). J. Acarol. Soc. Jpn., 14, 93-103.

11. Hinomoto, N., Shintaku, T. \& Amano, H. (2010) Comparison of genetic diversity among three phytoseiid mite species in Japan by mitochondrial DNA sequence analysis. $J$. Acarol. Soc. Jpn., 19, 9-14.

12. Hoy, M. A. (1982) Aerial dispersal and field efficacy of a genetically improved strain of the spider mite predator Metaseiulus occidentalis. Entomol. Exp. Appl., 32, 205212.

13. Hoy, M. A. (1985) Recent advances in genetics and genetic improvement of the Phytoseiidae. Annu. Rev. Entomol., 30, 345-370.

14. Johnson, D. T. \& Croft, B. A. (1976) Laboratory study of the dispersal behavior of Amblyseius fallacis (Acarina: Phytoseiidae). Ann. Entomol. Soc. Am., 69, 1019-1023.

15. Jung, C. \& Croft, B. A. (2000) Survival and plant-prey finding by Neoseiulus fallacis (Acari: Phytoseiidae) on soil substrates after aerial dispersal. Exp. Appl. Acarol., 24, 579-596.

16. Jung, C. \& Croft, B. A. (2001) Aerial dispersal of phytoseiid mites (Acari: Phytoseiidae): estimating falling speed and dispersal distance of adult females. Oikos, 94, 182-190.

17. Jung, C. \& Croft, B. A. (2001) Ambulatory and aerial dispersal among specialist and generalist predatory mites (Acari: Phytoseiidae). Environ. Entomol., 30, 1112-1118.

18. Matsuo, T. et al. (2003) Suitability of pollen as an alternative diet for Amblyseius cucumeris (Oudeman). Jpn. J. Appl. Entomol. Zool., 47, 153-158.

19. McMurtry, J. A. \& Croft, B. A. (1997) Life-styles of phytoseiid mites and their roles in biological control. Annu. Rev. Entomol., 42, 291-321.

20. Mochizuki, A. (2004) Method for assessing the indirect effects of introduced hymenopteran parasitoids on Japanese agricultural ecosystems. In Material circulation through agro-ecosystems in East Asia and assessment of its environmental impact. NIAES Ser. No. 5, ed. Hayashi, Y., NIAES, Tsukuba, Japan, 167-173.

21. Mochizuki, A. (2010) Invasive insects: problem and risk assessment. Extension Bulletins, FFTC for the Asian and Pacific Region, Taipei. http://www.agnet.org/library/eb/616/.

22. Mochizuki, M. et al. (2003) Indirect effects of exotic predatory mite, Typhlodromus occidentalis (Acari:Phytoseiidae), on native predatory mites in apple orchards in Akita Prefecture. Ann. Rept. Plant Prot. North Japan, 54, 174-176 [In Japanese with English summary].

23. Mochizuki, M. et al (2005) Species composition of phytoseiid mites in orchards after 13 years of exotic Typhlodro- 
mus occidentalis release. Ann. Rept. Kanto-Tosan Plant Prot. Soc., 52, 107-109 [In Japanese with English summary].

24. Mochizuki, M., Kimura, Y. \& Mochizuki, A. (2004) Environmental risk assessment of exotic phytoseiid mites on native phytoseiid mite species at the Aomori Apple Experiment Station. Ann. Rept. Plant Prot. North Japan, 55, 259-261 [In Japanese with English summary].

25. Nomikou, M., Janssen, A. \& Sabelis, M. W. (2003) Phytoseiid predators of whiteflies feed and reproduce on nonprey food sources. Exp. Appl. Acarol., 31, 15-26.

26. Overmeer, W. P. J. (1985) Diapause. In Spider mites. Their biology, natural enemies and control, vol. 1B, eds. Helle, W. \& Sabelis, M. W., Elsevier, Amsterdam, 95-102.

27. Sabelis, M. W. (1985) Development. In Spider mites. Their biology, natural enemies and control, vol. 1B, eds. Helle, W. \& Sabelis, M. W., Elsevier, Amsterdam, 43-53.

28. Sabelis, M. W. (1985) Predation on spider mites. In Spider mites. Their biology, natural enemies and control, vol. 1B, eds. Helle, W. \& Sabelis, M. W., Elsevier, Amsterdam, 103-129.

29. Sabelis, M. W. \& Janssen, A. (1994) Evolution of life-history patterns in the Phytoseiidae. In Mites. Ecological and evolutionary analyses of life-history patterns, ed. Houck, M. A., Chapman \& Hall, Inc., New York, 70-98.
30. Sekita, N. \& Kinota, M. (1990) Use of predatory mites to control spider mites (Acarina, Tetranychidae) on apple trees in Aomori Prefecture, Japan. In The use of natural enemies to control agricultural pests. FFTC Book Ser. No.40, ed. Bay-Petersen, J., FFTC for the Asian and Pacific Region, Taipei, 156-165.

31. van Houten, Y. M. et al. (1995) Selection for non-diapause in Amblyseius cucumeris and Amblyseius barkeri and exploration of the effectiveness of selected strains for thrips control. Entomol. Exp. Appl., 77, 289-295.

32. van Lenteren, J. C. et al. (2003) Environmental risk assessment of exotic natural enemies used in inundative biological control. BioControl, 48, 3-38.

33. van Lenteren, J. C. et al. (2006) Assessing risks of releasing exotic biological control agents of arthropod pests. Annu. Rev. Entomol., 51, 609-634.

34. van Rijn, P. C. J. \& Tanigoshi L. K. (1999) Pollen as food for the predatory mites Iphiseius degenerans and Neoseiulus cucumeris (Acari: Phytoseiidae): dietary range and life history. Exp. Appl. Acarol., 23, 785-802.

35. Veerman, A. (1992) Diapause in phytoseiid mites - a review. Exp. Appl. Acarol., 14, 1-60.

36. Yano, E. (2003) Natural enemies: ecology and biological control. Yokendo Ltd., Tokyo, pp.296 [In Japanese]. 